\title{
Mechanisms Fostering Social Entrepreneurship as Potential Instruments for Economic Development: The Eastern Partnership Perspective
}

\author{
Dāvis Plotnieks \\ Faculty of Economics and Management, \\ University of Latvia \\ Aspazijas blvd.5, \\ Riga LV-1050, Latvia \\ E-mail: davis.plotnieks@gmail.com
}

Abstract: With its plan to assign 600 million euros through the European Neighbourhood Instrument for Eastern Partnership countries, the European Union intended to increase the efficiency of institutions, attenuate social problems, and create an environment that fosters economic growth and human well-being in Armenia, Azerbaijan, Belarus, Georgia, Moldova, and Ukraine. A few scholars have criticized the amount of funding and planned initiatives of the European Neighbourhood Instrument as insufficient and suggested that in order to foster cooperation and support reforms in its Eastern Partnership countries, more action should be taken. In times when European Commission budget is under constraints of consolidation and increase of aid for supporting European Neighbourhood countries is hardly possible, alternative solutions for tempering social problems need to be assessed. Various scientists, philanthropists and entrepreneurs see social entrepreneurship as a tool for solving social problems in a sustainable way where business thinking is being combined with non-profit philosophy. Contrary to government support and intervention for solving social problems, social entrepreneurship is already being used as tool that initially addresses joint needs — solve social problems and create revenue that provides much needed income for sustainable business initiatives. This paper analyzes the concept of social entrepreneurship, examples where social entrepreneurship is solving social problems, and mechanisms that can foster these phenomena. The aim of this paper is to examine different mechanisms of how governments can foster the creation and development of social entrepreneurship. Unique survey data 
derived from a project examining social entrepreneurship in Europe is used. It is concluded that by adopting mechanisms proven in various developed countries, the Eastern Partnership countries can stimulate social entrepreneurship, thus attenuating social problems and creating environment that fosters economic growth and the wellbeing of people.

Keywords: Eastern Partnership, social entrepreneurship, mechanisms for social entrepreneurship

\section{Introduction}

The Eastern Partnership Initiative (EaP), introduced by the European Union (EU), was targeted towards stimulation of cooperation and support of reforms in EU Eastern Neighbourhood countries: Armenia, Azerbaijan, Belarus, Georgia, Moldova, and Ukraine. In its communication to the European Parliament and the Council on Eastern Partnership, the European Commission (2008, p. 15) reported that the rationale of $\mathrm{EaP}$ is "To promote better governance and economic development through a determined engagement in its neighbourhood". Some scholars have argued that EaP has not met everybody's expectations because of its insufficient funding and equal approach to six different countries (e.g., Łapczyński, 2009, p. 143; Boonstra \& Shapovalova, 2010, p. 1; Kelley, 2006, p. 50). Scholars have estimated that EaP funding is only 0.44 per cent of the partner-countries' GDP forecast for 2010 (Franke et al., 2010, p. 153). However, some admit that since EaP initiatives were designed according to previously tested mechanisms of the EU enlargement which have already demonstrated their effects, its contribution towards democratic and economic reforms is not insubstantial (e.g., Bosse \& Korosteleva-Polglase, 2009, p. 145; Schäffer \& Tolksdorf, 2009, p. 1). Even if the EU's limited aid for the economic development of EaP countries reduces the amount, scale and speed of economic reforms, there are other mechanisms that can be used to foster economic growth and human well-being.

Scholars, entrepreneurs and policy-makers increasingly see the phenomenon of social entrepreneurship as an initiative in which social value and good is placed in the forefront of traditional business approach with individual gains (e.g., Amorós \& Bosma, 2014, p. 16; Thompson \& Doherty, 2006, p. 362; European Commission, 2011, p. 2). The number of research studies on social entrepreneurship and academic journals published on this topic has also increased 
(e.g., Tracey \& Jarvis, 2007, p. 678; Dacin et al., 2010, p. 49), demonstrating the societal benefits from social entrepreneurial activity. The worlds' top business schools include social entrepreneurship in their syllabi, while only a decade ago this was a rare choice in business schools (Sen, 2007, p. 552).

Contrary to government support and intervention, social entrepreneurship unleashes the entrepreneurial spirit of individuals to solve social problems. Investors have already proved that they value investment into social entrepreneurship. Investment professionals using the framework for measuring the potential size for investment in social entrepreneurship until 2020, have estimated the opportunity for invested capital to 400 billion to 1 trillion U.S. dollars (O'Donohoe et al., 2010, p. 6). These features show the growing importance and scale of how scholars, practitioners and policy-makers see social entrepreneurship and its contribution to solving social problems.

This paper examines how social entrepreneurship can serve as an instrument to temper social problems and how it can be used as an alternative solution for direct government aid. In the first section, the concept of social entrepreneurship is analyzed, explaining the nature of this phenomenon. Definitions of social entrepreneurship and development in scientific literature are provided. In the following section, examples of social entrepreneurship ventures from different case studies are used to explain social impact. Using existing evidence from literature and unique panel dataset from SELUSI project with surveys over 550 social entrepreneurs in Europe, policy suggestions for fostering social entrepreneurship were gathered. The article contributes to the existing theory and practices in the comprehension of social entrepreneurship phenomena and explains the mechanisms fostering social entrepreneurship.

\section{The concept of social entrepreneurship}

Various definitions try to capture the essence of social entrepreneurship (e.g., Terjesen et al., 2012, p. 4). The views of practitioners, scholars, social entrepreneurs, and other experts of the field vary and the boundaries of social entrepreneurship are blurred. Some scholars define social entrepreneurs through their strong respect to social mission in contrast to other organizational forms (Nicholls \& Cho, 2006, p. 115). Others suggest that the creation of positive social outcomes (Seelos \& Mair, 2007, p. 51; Austin et al., 2006, p. 2), or applying business approach in mitigating social problems (Thompson \& Doherty, 2006, p. 362), characterize social entrepreneurs. Practitioners suggest 
that entrepreneurial initiatives or activities that generate market-based revenues with social, environmental and community objectives can represent social entrepreneurship (Terjesen et al., 2012, p. 4).

For some experts in the field, the blurred boundaries of definitions raise questions about how social entrepreneurship differs from non-governmental organizations (NGOs). Indeed, both of these forms of human activity have their mission based on social goals rather than on commercial ones. Scholars suggest that organizations can be classified as NGOs if they represent values of voluntarism, pluralism and altruism (DiMaggio \& Anheier, 1990, p. 153). Others suggest that NGOs represent the needs of socially vulnerable groups and promote civic society, while, in specific cases, claiming tax advantages and attracting philanthropic funds (Maddison, \& Hamilton, 2007, pp. 80, 98). Even though these characteristics may seem similar, differences between these two forms exist both for NGOs and social entrepreneurs. Mission-related income, entrepreneurial risk and creation of social value to contribute to the well-being of others distinguish social entrepreneurs from other forms of civic activity.

Fundamental differences exist also between traditional entrepreneurship, the participants of which are profit-driven, and social entrepreneurship, where social outcomes and social impact dominate over monetary rewards. Capability to pursue opportunities, use of innovative approaches in problem-solving and taking on entrepreneurial risks (Peredo \& McLean, 2006, p. 64) characterize both forms of entrepreneurship. According to a research, in the course of which interviews of 150,000 adults in 49 countries were conducted, practitioners define social entrepreneurship as an activity that creates value for community and solves social problems (Terjesen et al., 2012, p. 10). Intrinsically motivated focus on the social benefits for community over monetary rewards distinguishes social entrepreneurs from commercially oriented or traditional ones.

The specific characteristics of social entrepreneurship complicate the measuring and evaluation of this entrepreneurial activity. Traditional methods that capture the results of entrepreneurial endeavour, such as disclosure statements, reports, and project evaluations, focus on short-term impacts. These evaluation methods do not capture the long-term impact of social entrepreneurship (Ebrahim, 2003, p. 826). Scholars have tried to provide different approaches and various methods to capture and measure the social impact of social entrepreneurs (Ebrahim \& Rangan, 2010, p. 34; Antadze \& Westley, 2012, p. 144). These alternatives include focusing on resources and inputs that social enterprises use for their entrepreneurial activity and outputs and outcomes that contribute to the fulfilment of their mission. No single and globally accepted standard for measuring social 
income exists. The concept and definitions of social entrepreneurship, whether defined by scholars or drawn up by practitioners, puts at the forefront its beneficial effects to society. The field of academic research on this phenomenon is in its development stage. Empirical work and data on explaining the beneficial impact of social entrepreneurship in long term is scarce. Therefore, to understand the importance of social entrepreneurship it is essential to analyze specific cases and activities of this phenomenon.

\section{Social entrepreneurship as an instrument for solving social problems}

Data on social entrepreneurship collected by researchers at the Global Entrepreneurship Monitor shows that there are at least five industries globally, where social entrepreneurs represent more than 5 per cent of all market participants in the industry. The largest proportion of for-profit social entrepreneurs is represented in social services industry $(21.1 \%)$, followed by culture and recreation (11.9\%), development and housing (7.4\%), education and research $(5.5 \%)$ and environment (5.4\%). According to the report, 32 per cent of early-stage social entrepreneurs in the United States represent social services industry, helping vulnerable groups such as the elderly or the poor, and former prisoners. The situation is similar in Latin America, where 31.3 per cent of social entrepreneurial activity is based on social services industry. In Eastern Europe, 20.5 per cent of social entrepreneurial activity is carried out in social services, while in Africa the highest proportion $(28.9 \%)$ is in development and housing industry followed by social services (21.1\%) (Terjesen et al., 2012, p. 27). These data show that social entrepreneurship can represent diverse industries representing an essential share of products and services which facilitate the reduction of social problems.

To understand and examine the impact of social entrepreneurship, scholars analyze existing cases of social ventures. Such social enterprises as the Bangladesh Rural Advancement Committee, Grameen Bank and Self-Employed Women's Association have reached millions of people and fostered social transformation (Alvord et al., 2004, p. 280). Grameen Bank, a micro lending institution for the socially insecure people, has provided financing opportunities for more than 8 million borrowers. The Bangladesh Rural Advancement Committee, providing education, skills and entrepreneurial training for the poor, by their own estimates has reached 135 million people. Another group of scholars, analyzing the impact of social entrepreneurs (Thompson \& Doherty, 2006, p. 363), explored 11 cases in 
which social ventures have abated social problems. The cases of Genesis, Suma, KaBoom!, Play Pumps, Trade Plus Aid, Cafedirect, Honey Care, Easybeinggreen, Trinity Partnership, Train 2000, Merseyside Dance Initiative, allow exploring the social outcomes produced. In each of these cases social ventures represent different industries, but the unifying aspect is their contribution to the society. Providing community-based services in the East Midlands, U.K., Genesis has helped local community by training people in necessary skills, providing opportunities of childcare and family sports and even affordable dental services. KaBoom!, producer and distributor of children playgrounds operating in the U.S.A., with the help of more than 65,000 volunteers, has built 338 new playgrounds for children in seven years. Cafedirect, a fair-trade social enterprise, with the aim to help marginalized coffee farmers, paying not only market rates for their production but also a premium that is invested into community infrastructure projects, has helped 250,000 families to earn a tolerable income. Guide Dogs for the Blind Association (Austin et al., 2006, p. 7), an organization based in the U.K. with a mission to help blind and partially sighted people, helps more than 800 people annually.

Commercially motivated companies willing to expand their market in new areas might also use benefits from social entrepreneurship. In countries with little purchasing power, due to low GDP levels per inhabitant, commercially driven companies might cooperate with social entrepreneurs. Scholars suggest that in partnering with social entrepreneurs, companies can analyze their business model and environment and provide solutions for customer segments, which previously were seen inaccessible (Seelos \& Mair, 2007, p. 61). Partnering is essential when considering scaling up social outcomes. Collaboration with other organizations can work as a facilitator for scaling (Austin et al., 2006, p. 18). Bringing together social resources from a few organizations and transforming them to social outputs and outcomes can scale up social impact.

The lack of metrics for measuring social entrepreneurship, its impact and scope, makes it difficult to evaluate as to what extent are the global social problems being solved. A research report by Chaves and Monzón (2007, p. 6) estimated that only in year 2005 , over 240,000 cooperatives, mutual societies, associations and foundations were economically active in EU-25. Driven by ideals and moral values, these organizations ensured direct employment to 3.7 million people. In reality, the definition and scope of social entrepreneurship differs from cooperatives, mutual societies and foundations; however, it shows that employment is positively affected by the presence of these organizations.

Different ways of how to measure the extent by which social entrepreneurship solves social problems in various industries will be on the agenda of researchers, 
policy-makers and practitioners for a while. Case studies from different fields of successful social ventures around the world show positive effects on society, which are hardly deniable. Even though the participation rates of social entrepreneurs are above 5 per cent in few industries only, the presence of social ventures can be observed in more than 12 different mainstream industries all around the world (Terjesen et al., 2012, p. 27). Policy-makers in various countries recognize that social entrepreneurship can be used as an instrument for solving social problems, and therefore it is important to explore mechanisms for fostering social entrepreneurship.

\section{Mechanisms for fostering social entrepreneurship}

\subsection{Measuring social impact}

The necessity to measure social impact has been agreed upon by several scholars (e.g., Ebrahim, 2003, p. 826; Ebrahim \& Rangan, 2010, p. 34; Antadze \& Westley, 2012, p. 144; Nicholls, 2009, p. 766). Researchers admit that measurement allows evaluation of the social impact of a venture, comparing it with other market players and attracting investment. Ventures fulfilling their missions are more successful in attracting much needed talent and investment (BuggLevine et al., 2012, p. 5). Efficient metrics for performance measurement allow capturing social impact, which is a significant criterion for impact investors in making decisions where to invest (Bugg-Levine \& Emerson, 2011, p. 13). There are a variety of social investors, such as development financial institutions, private foundations, large-scale financial institutions, private wealth managers, commercial banks, retirement fund managers, boutique investment funds, companies and community development financial institutions (O'Donohoe et al., 2010, p. 15). Taking into account the variety of investor types, the investors' measurement policies may differ. According to an impact investor survey, conducted by J.P.Morgan and Global Impact Investment Network, 98 per cent of 125 surveyed investors admitted that standardized impact metrics is to some extent important (Saltuk, 2014. p. 17). Available research literature shows that globally accepted impact measurement standards do not exist. To attract investors' attention and "speak the same language" when developing their strategy and setting accountability procedures, social entrepreneurs can adopt some measurement standards applied by investors of the same industry. Practitioners (e.g., Drexler et al., 2013, p. 32) suggest standards used by various impact investors such as Impact Reporting and Investment Standards (IRIS) or Global Impact Investing Rating System (GIIRS). Since they are already used 
by investors these standards have the much needed credibility and know-how of their effective usage.

Impact investment allows social entrepreneurs to start their ventures and, most importantly, to scale these up. Scaling a venture provides an opportunity to reach new markets and scale social impact. The lack of transparent ways of how to measure, report and monitor social outcomes withholds capital markets from investing in social entrepreneurship initiatives (e.g., Kaplan \& Grossman, 2010). Existing research systematically point out the need to measure social impact. The choice for using specific metrics will be in the hands of social entrepreneurship. When choosing any of available metrics or developing new ones, it is important to take into account which purpose the metrics will serve. To attract investors, practitioners suggest to adopt already established metrics used by investors. If attracting investment is not a priority for social entrepreneur but instead achievement of social mission is of importance, metrics capturing inputs, skills, outputs and outcomes might be developed by themselves.

\subsection{Environment for social entrepreneurship}

Institutional environment for social entrepreneurship differs from country to country. While in the U.S.A., it has been mostly represented by the rules and practices of business and private sector, in Western Europe institutional environment is mostly shaped by the social services and government sector practices that are non-profit driven (Kerlin, 2006, p. 254). The contrast between the U.S.A. and Western Europe is being deepened by financial support where organizations in the U.S.A. attract more support from private sources, while in Western Europe government plays a leading role (Paton, 2003, p. 27). Some scholars (e.g., Peredo \& McLean, 2006, p. 57) suggest that actions in the form of supportive legislation and other policy assistance are worth discussing to stimulate social entrepreneurship. Practitioners support the idea that government interference is important (CUA, 2006, p. 2). Considering the limits of government support, it is useful to examine the aspects of creating an environment favourable to social entrepreneurship. Setting rules and incentives where social entrepreneurship can flourish by providing alternative stimulus rather than using direct financial support from government, is a way how social entrepreneurship can be developed.

Taking into consideration the viewpoint of investors, data from the impact investor survey provide valuable insights. Investors consider specific government policies that provide tax credits, credit enhancement or subsidies that would improve returns from social investment as the most useful support mechanisms. However, 
clear and foreseeable regulations were also indicated as favourable government support (Saltuk, 2014, p. 17). This signals the necessity for government authorities to create an environment where transparent and predictable rules exist, so that investors can count on the established rules and plan their investments accordingly. Lessons from the already established industries show that the creation of attractive environment for investors happens when industry leaders work towards elimination of barriers and foster policy change (Freireich \& Fulton, 2009, p. 23).

Public support in the form of building community awareness and communication and participation as a partner in realization of social programs also enhances social entrepreneurship (Korosec \& Berman, 2006, p. 457). In some EU countries, specific legal forms for social entrepreneurship have been created. In the U.K., the Parliament passed a legislation in 2005 approving the new legal form of the Community Interest Company, aiming to foster growth of new social ventures (Nicholls, 2010, p. 394). Countries like Italy, France, Spain, Portugal, and Greece also introduced in their national legislation new legal forms aiming to stimulate social innovation. These forms not always represent social entrepreneurship, since several of them reflect non-profit legal forms (Defourny \& Nyssens, 2008, p. 206). Some scholars suggest that specific legal forms help social entrepreneurs complement government services in various industries, such as social housing, ensuring childcare services, transport for community, and leisure activities (DTI, 2003, p. 29). Since the field of social entrepreneurship research is still only developing, the amount of data and evidence on mechanisms supporting social entrepreneurship is scarce. In such circumstances evidence from social entrepreneurs can provide valuable and practical insights into this dynamic phenomenon and into which improvements should be introduced.

\subsection{Policy suggestions}

To capture the viewpoint of social entrepreneurs on their operational models, sources of financing, resources and barriers hindering creation and growth of social entrepreneurship, a specific survey was launched. From November 2009 until March 2010, a novel panel of database was created in the framework of the Selusi project. Telephone interviews were carried out with social entrepreneurs from Hungary, Romania, Spain, Sweden, and the United Kingdom, using specific sampling technique called respondent-driven sampling, typically employed in interviewing hard-to-reach populations. Specially trained interviewers ensured 
that questions were asked and explained in a manner that allowed collecting comparable answers. From all the data collected 30 per cent of responses were double scored to ensure high inter-rater reliability ensuring the agreement between evaluators that ratings given by them are homogeneous. Among other questions which fall outside the scope of this article, social entrepreneurs were asked for recommendations that would improve the environment where they operate and advance change in policy at the EU level. Valid responses were collected from 582 respondents. Respondent distribution across countries is represented in Figure 1.

The collected data differs between countries and in each of the respondent countries the most frequently suggested options also vary. Since social entrepreneurs provided many different answers when asked about their preferred policy change, only the most significant and popular suggestions are described in Figure 2.

Figure 1. Number of responses collected for policy suggestions (Huysentruyt et al., 2010)

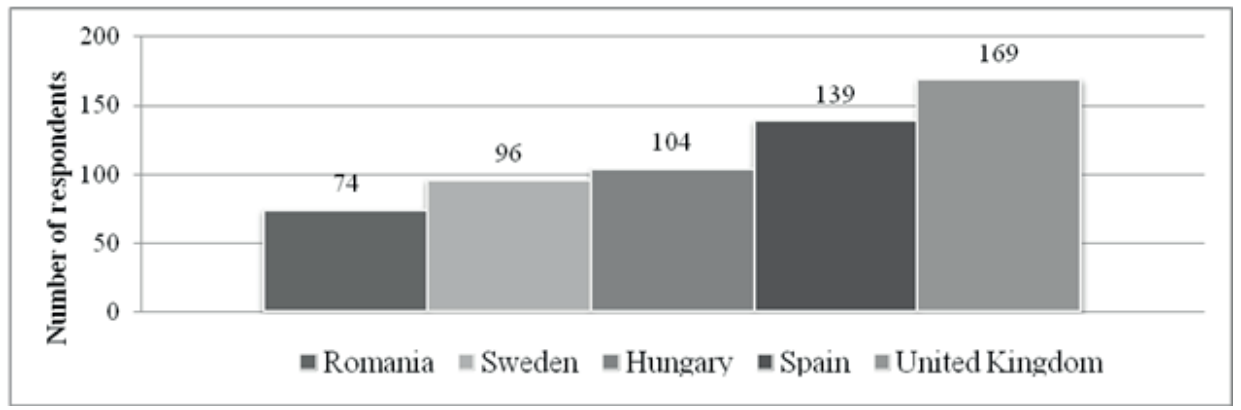

Figure 2. Policy suggestions by social entrepreneurs (Huysentruyt et al., 2010)

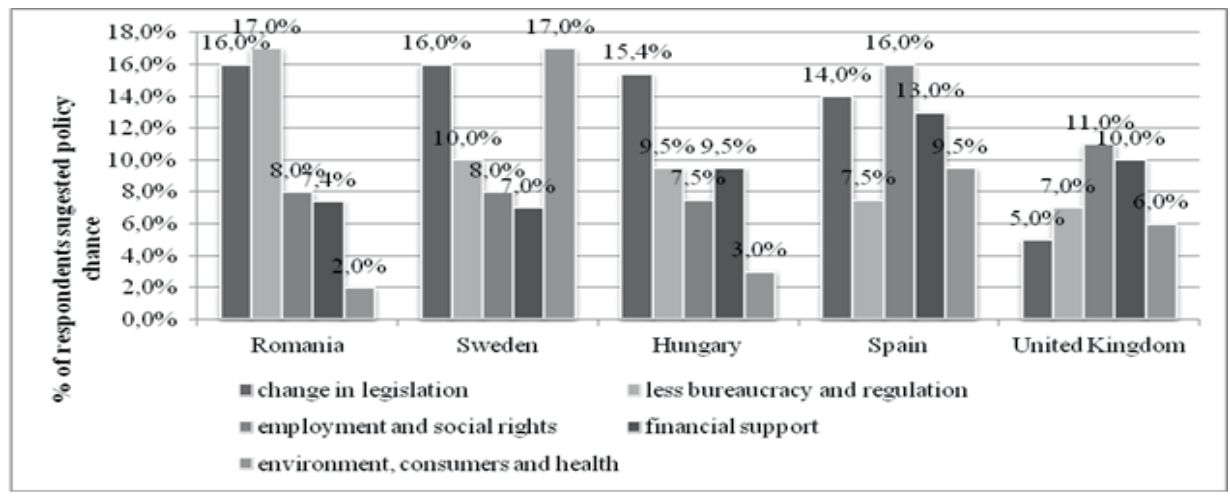


As the top suggestion on policy change, 15.4 per cent of social entrepreneurs in Hungary recognize change in legislation. In other surveyed countries, change in legislation was not mentioned as the most frequent answer from respondents among other suggestions. However, the frequency mentioning change in legislation by respondents from other surveyed countries are significantly higher, for instance: Romania 16\%, Sweden 16\%, Spain 14\%, and United Kingdom 5\%. It is important to stress that change in legislation is the most frequently mentioned suggestion by social entrepreneurs. The implementation of this suggestion might differ and it depends on the circumstances and existing environment in particular country how to approach it, but this indicates that non-financial support of the government is very important. In comparisonaccording to the data, such government assistance as tax breaks seems to be less important-Romania 6\%, Sweden 8\%, Hungary 4\%, United Kingdom 5\%. As the second most often used suggestion, on average, respondents mentioned less bureaucracy and regulation-Romania $17 \%$, Sweden $10 \%$, Hungary $9.5 \%$, Spain $7.5 \%$, United Kingdom 7\%. Similarly to change in legislation, lowering the regulatory burden is in the hands of government. The choice is either to mitigate the procedures for oversight of social entrepreneurs and invest government resources in the optimization of the bureaucracy and regulations or implement strict control and reporting procedures. Respondents also emphasize the need to improve employment policy and social rights. It is worth noting that this suggestion occurs most frequently in Spain-16\%, while in other countries the importance of this suggestion is lower-Hungary $7.5 \%$, Romania $8 \%$, Sweden $8 \%$, United Kingdom $11 \%$. Other frequent policy suggestions were financial support-Romania 7.4\%, Sweden 7\%, Hungary 9.5\%, Spain 13\%, United Kingdom 10\%-and improvements in environment, consumers and healthRomania 2\%, Sweden 17\%, Hungary 3\%, Spain 9.5\%, United Kingdom 6\%.

Survey data shows that, on average, the most frequent suggestions by social entrepreneurs for policy recommendations include non-financial support from policy-makers. It shows that mechanisms to foster social entrepreneurship cover improvements on legislation, reduction of bureaucracy and regulation, advances in employment rights and social security that can be implemented without direct government financial support. Social entrepreneurs suggest improving the financial support for ventures, environment and policies affecting consumer wellbeing. 


\section{Conclusions and further research}

This study examined economic development through the prism of social entrepreneurship. Using the definitions outlined by scholars and practitioners it demonstrated the spirit and essence of social entrepreneurship, which still lacks common and widely accepted definitions in scientific literature. Since the research literature on social entrepreneurship as a rather new phenomenon continues to develop, the empirical evidence on macro level is rather scarce. While case studies show undeniable facts that social problems have been abated by social entrepreneurship, comparable data on social impact on the global scale is not available.

This article demonstrates that there are alternatives to insufficient government care or financial aid for solving social problems. In the context of EaP, this article established that social entrepreneurship could be used as a tool for improving human well-being. By applying the entrepreneurial spirit in different industries, social problems can be addressed via social venture creation. According to scientific literature, various research data and surveyed social entrepreneurs, there are different mechanisms that can foster social entrepreneurship. Measurement of social impact can be used as a tool for existing social entrepreneurs to scale up their operations by attracting investors who would be willing to invest in ventures generating social impact. Measurement of social impact allows attracting talent and evaluating the fulfilment of social mission. Improvement of environment involves the creation of rules and practices, where impact investors can consider the consistency of policies and regulations introduced by government to stimulate their interest to invest in social ventures. Policy support is essential and several EU countries have already introduced in their legislation specific legal forms for social enterprises. In the surveyed countries, social entrepreneurs recognize that mechanisms to foster social entrepreneurship cover the improvements on legislation, reduction of bureaucracy and regulation, and advances in employment rights and social security.

This article contributes to the existing theory and practice in the comprehension of social entrepreneurship phenomena and explains mechanisms fostering social entrepreneurship. However, to understand the nuances of developing social entrepreneurship, further research and data on policy implications in terms of specific mechanisms introduced is much needed. 
Dāvis Plotnieks is research assistant at the Stockholm Institute for Transition Economics at the Stockholm School of Economics (Stockholm, Sweden). His main research interests cover social entrepreneurship, in particular social finance and impact investing and innovation management. He is lecturer of Business Management at the BA School of Business and Finance (Riga, Latvia), where he teaches master programmes, most recently Innovation Management. Davis is a Ph.D. student in Economics at the University of Latvia and holds a master's degree in Business Administration at the BA School of Business and Finance.

\section{Bibliography}

Alvord, S. H.; Brown, L. D. \& Letts, C. W. (2004), 'Social Entrepreneurship and Societal Transformation An Exploratory Study,' The Journal of Applied Behavioral Science, vol. 40, no. 3, pp. 260-282. http://dx.doi.org/10.1177/0021886304266847

Amorós, J. E. \& Bosma, N. (2014), 'Global Entrepreneurship Monitor,' in 2013 Global Report, London: Global Entrepreneurship Research Association (GERA).

Antadze, N. \& Westley, F. R. (2012), 'Impact Metrics for Social Innovation: Barriers or Bridges to Radical Change?' Journal of Social Entrepreneurship, vol. 3, no. 2, pp. 133-150. http://dx.doi.org/10.1080/19420676.2012.726005

Austin, J.; Stevenson, H. \& Wei-Skillern, J. (2006), 'Social and commercial entrepreneurship: same, different, or both?' Entrepreneurship Theory and Practice, vol. 30, no. 1, pp. 1-22. http://dx.doi.org/10.1111/j.1540-6520.2006.00107.x

Boonstra, J. \& Shapovalova, N. (2010), The EU's Eastern Partnership: One Year Backwards, Working Paper 99, Madrid: FRIDE.

Bosse, G. \& Korosteleva-Polglase, E. (2009), 'Changing Belarus? The limits of EU governance in Eastern Europe and the promise of partnership,' Cooperation and Conflict: Journal of the Nordic International Studies Association, vol. 44, no. 2, pp. 143-165.

Brooks, A. C. (2009), Social Entrepreneurship: A Modern Approach to Social Value Creation, New Jersey: Pearson Prentice Hall.

Bugg-Levine, A. \& Emerson, J. (2011), Impact Investing: Transforming How We Make Money While Making a Difference, San Francisco: Wiley Imprint.

Bugg-Levine, A.; Kogut, B. \& Kulatilaka, N. (2012), 'A new approach to funding social enterprises,' Harvard Business Review, Reprint no. R1201K, pp. 1-7.

Chaves, R. A. \& Monzón, J. L. (2007), The Social Economy in the European Union, Report drawn up for the European Economic and Social Committee by the International Centre of Research and Information on the Public, Social and Cooperative Economy (CIRIEC). 
CUA (2006), A Social Investment Bank, Consultation paper of the Commission on Unclaimed Assets, United Kingdom. Retrieved from http://www.ronaldcohen.org/ sites/default/files/1/CUA_ConsultationPaper.pdf [accessed 9 Jun 2014]

Dacin, P. A.; Dacin, M. T. \& Matear, M. (2010), "Social entrepreneurship: why we don't need a new theory and how we move forward from here," The Academy of Management Perspectives, vol. 24, no. 3, pp. 37-57. http://dx.doi.org/10.5465/AMP.2010.52842950

Defourny, J. \& Nyssens, M. (2008), 'Social enterprise in Europe: recent trends and developments,' Social Enterprise Journal, vol. 4, no. 3, pp. 202-228.

DiMaggio, P. J. \& Anheier, H. K. (1990), 'The sociology of non-profit organizations and sectors,' Annual Review of Sociology, vol. 16, pp. 137-159. http://dx.doi.org/10.1146/annurev.so.16.080190.001033

Drexler, M.; Noble, A. \& Bryce, J. (2013), From the Margins to the Mainstream: Assessment of the Impact Investment Sector and Opportunities to Engage Mainstream Investors, Geneva: World Economic Forum, Switzerland.

DTI (2003), A Progress Report on Social Enterprise: A Strategy for Success Department of Trade and Industry, London: Department of Trade and Industry.

Ebrahim, A. (2003), 'Accountability in practice: Mechanisms for NGOs,' World Development, vol. 31, no. 5, pp. 813-829.

Ebrahim, A. S. \& Rangan, V. K. (2010), The Limits of Nonprofit Impact: A Contingency Framework for Measuring Social Performance, Harvard Business School General Management Unit Working Paper, no. 10-099. http://dx.doi.org/10.1016/S0305-750X(03)00014-7

European Commission (2008), Eastern Partnership, COM(2008) 823, European Commission, 3 December 2008. Retrieved from http://ec.europa.eu/europeaid/ where/neighbourhood/eastern_partnership/documents/eastern_partnership_ communication_from_the_commission_to_the_european_parliament_and the council_en.pdf [accessed 6 May 2014]

(2011), Social Business Initiative: Creating a favourable climate for social enterprises, key stakeholders in the social economy and innovation, COM(2011) 682, European Commission, 25 October 2011. Retrieved from http://eur-lex. europa.eu/LexUriServ/LexUriServ.do?uri=COM:2011:0682:FIN:EN:PDF [accessed 8 May 2014]

Franke, A.; Gawrich, A.; Melnykovska, I. \& Schweickert, R. (2010), "The European Union's Relations with Ukraine and Azerbaijan," PostSoviet Affairs, vol. 26, no. 2, pp. 149-183. http://dx.doi.org/10.2747/1060-586X.26.2.149

Freireich, J. \& Fulton, K. (2009), Investing for Social and Environmental Impact: A Design for Catalyzing an Emerging Industry, Cambridge, MA: The Monitor Group. 
Huysentruyt, M.; Rimac, T.; Stephan, U.; Essen, E. \& Vujić, S. (2010), Personalized Country Feedback Reports, Selusi Research Consortium. Retrieved from http:// www.selusi.eu/index.php?page=business-platform [accessed 4 July 2014]

Kaplan, R. S. \& Grossman, A. S. (2010), 'The emerging capital market for nonprofits,' Harvard Business Review, vol. 88, no. 10, pp. 110-118.

Kelley, J. (2006), 'New Wine in Old Wineskins: Promoting Political Reforms through the New European Neighbourhood Policy,' JCMS: Journal of Common Market Studies, vol. 44, no. 1, pp. 29-55.

Kerlin, J. A. (2006), 'Social enterprise in the United States and Europe: Understanding and learning from the differences,' Voluntas: International Journal of Voluntary and Nonprofit Organizations, vol. 17, no. 3, pp. 246-262. http://dx.doi.org/10.1007/s11266-006-9016-2

Korosec, R. L. \& Berman, E. M. (2006), 'Municipal support for social entrepreneurship,' Public Administration Review, vol. 66, no. 3, pp. 448-462.

Lapczyński, M. (2009), “The European Union's Eastern Partnership: Chances and Perspectives," Caucasian Review of International Affairs, vol. 3, no. 2, pp. 143155.

Maddison, S. \& Hamilton, C. (2007), Non-Government Organisations. Silencing Dissent: How the Australian Government is controlling public opinion and stifling debate, Sydney: Allen and Unwin.

Nicholls, A. (2009), "We Do Good Things Don't We?: Blended Value Accounting in Social Entrepreneurship," Accounting, Organizations and Society, vol. 34, nos. 6-7, pp. 755-769. http://dx.doi.org/10.1016/j.aos.2009.04.008

(2010), 'The institutionalization of social investment: The interplay of investment logics and investor rationalities,' Journal of Social Entrepreneurship, vol. 1, no. 1, pp. 70-100.

http://dx.doi.org/10.1080/19420671003701257

Nicholls, A. \& Cho, A. H. (2006), 'Social entrepreneurship: The structuration of a field,' in A. Nicholls (ed.) Social Entrepreneurship: New Models of Sustainable Social Change, Oxford: Oxford University Press, pp. 99-118.

O'Donohoe, N.; Leijonhufvud, C.; Saltuk, Y.; Bugg-Levine, A. \& Brandenburg, M. (2010), Impact Investments: An Emerging Asset Class, J.P.Morgan, The Rockefeller Foundation \& Global Impact Investing Network.

Paton, R. (2003), Managing and Measuring Social Enterprises, London: Sage.

Peredo, A. M. \& McLean, M. (2006), 'Social entrepreneurship: A critical review of the concept,' Journal of World Business, vol. 41, no. 1, pp. 56-65. http://dx.doi.org/10.1016/j.jwb.2005.10.007

Saltuk, Y.; Idrissi, A. E.; Bouri, A.; Mudaliar, A. \& Schiff, H. (2014), Spotlight on the Market: The Impact Investor Survey, Global Social Finance, J.P.Morgan.

Schäffer, S. \& Tolksdorf, D. (2009), The Eastern Partnership - "ENP plus” for 
Europe's Eastern Neighbors, CA Perspectives, no. 4, Center for Applied Policy Research \& Ludwig-Maximilians-Universität Munich.

Seelos, C. \& Mair, J. (2007), 'Profitable business models and market creation in the context of deep poverty: a strategic view,' Academy of Management Perspectives, vol. 21, no. 4, pp. 49-63.

http://dx.doi.org/10.5465/AMP.2007.27895339

Sen, P. (2007), “Ashoka's big idea: Transforming the world through social entrepreneurship," Futures, vol. 39, no. 5, pp. 534-553.

http://dx.doi.org/10.1016/j.futures.2006.10.013

Terjesen, S.; Lepoutre, J.; Justo, R. \& Bosma, N. (2012), The Global Entrepreneurship Monitor: Report on Social Entrepreneurship 2009, Babson Park, MA \& Santiago, Chile \& London: Babson College \& Universidad del Desarrollo \& Global Entrepreneurship Research Association.

Thompson, J. \& Doherty, B. (2006), 'The diverse world of social enterprise: A collection of social enterprise stories,' International Journal of Social Economics, vol. 33, nos. 5/6, pp. 361-375. http://dx.doi.org/10.1108/03068290610660643

Tracey, P. \& Jarvis, O. (2007), 'Toward a theory of social venture franchising,' Entrepreneurship Theory and Practice, vol. 31, no. 5, pp. 667-685. http:// dx.doi.org/10.1111/j.1540-6520.2007.00194.x

Wood, D.; Thornley, B. \& Grace, K. (2012), Impact at Scale: Policy Innovation for Institutional Investment with Social and Environmental Benefit, Pacific Community Ventures, Institute for Responsible Investment at Harvard University \& Rockefeller Foundation. Retrieved from http://www.rockefellerfoundation.org/ blog/impact-scale-policy-innovation [accessed 20 May 2014] 